\title{
Teknik Sipil
}

\section{DAFTAR ISI}

Pengaruh Variasi Gradasi Agregat (SLAG) Terhadap Kuat Tekan, Porositas Dan Kuat Tarik Belah Beton Abd. Basid ${ }^{1}$, Yusuf W ${ }^{2}$

Manajemen Waktu, Biaya dan SDM Proyek Konstruksi pada Pembangunan Gedung Ruang Kuliah Fia Universitas Brawijaya Malang dengan Menggunakan Metode Pert dan PDM

Anugerah Fakhrur Rozy ${ }^{1}$, Ode R.G.W. ${ }^{2}$ $.10-19$

Studi Perilaku Campuran Lataston (HRS-WC) dengan "Limbah Karet Ban Luar" Sebagai Bahan Pengganti Sebagian Aspal

Candra Putra Kiswara ${ }^{1}$, Andi Saiful $\mathbf{A}^{2}$. $20-29$

Pengaruh Penggunaan Serat High Density Polyethylene (HDPE) pada Campuran Beton Terhadap Kuat Tarik Beton

Erwin Rommel ${ }^{1}$, Yunan Rusdianto ${ }^{2}$, Anita Kurniati ${ }^{3}$ $.30-37$

Analisa Biaya dan Waktu dengan Menggunakan Metode Time Cost Trade Off pada Proyek Pembangunan Hotel Aston Paramount Malang

Iktiva Sani ${ }^{1}$, Zamzami Septiropa ${ }^{2}$ $.38-47$

Studi Evaluasi dan Perencanaan Sistem Jaringan Drainase Kecamatan Rogojampi Kabupaten Banyuwangi Muamar Khadafi', Ernawan Setyono ${ }^{2}$. $48-55$

Penggunaan Sambungan Bambu Ori Menggunakan Baut pada Kuda-Kuda dengan Pengisi Mortar Resin Muhammad Haris ${ }^{1}$,Lukito Prasetyo ${ }^{2}$ $56-62$

Pengaruh Bottom Ash Sebagai Pengganti Pasir dan Limbah Karbit Sebagai Bahan Tambah Semen Terhadap Berat Jenis, Kuat Tekan, dan Absorbsi Batako

Nur Ali ${ }^{1}$, Rofikatul Karimah ${ }^{2}$, H. E.Meiyanto ${ }^{3}$. $63-70$

Studi Perencanaan TPA Masukau dengan Sistem Sanitary Landfill di Kabupaten Tabalong Kalimantan Selatan Rahmat Nazhary ${ }^{1}$, Ir.Warih K ${ }^{2}$ $.71-79$

Ptimasi Diameter Pipa pada Sistem Jaringan Air Bersih dengan Menggunakan Linear Programming di Kecamatan Turen Malang

Rega Putra Permana ${ }^{1}$, Chairil Saleh ${ }^{2}$ $80-90$

Evaluasi Kinerja Angkutan Umum Penumpang Kota Malang pada Jalur GA (Hamid Rusdi - Arjosari)

Tri Asmaraning Tyas A M ${ }^{\mathbf{1}}$, Alik Ansyori ${ }^{2}$. $.91-99$ 